\title{
Cytological features of non-small cell carcinomas of the lung in fine needle aspirates
}

\author{
S B Zusman-Harach, H R Harach, A R Gibbs
}

\begin{abstract}
Fifty eight lung tumours were typed according to the second World Health Organization histological classification and compared with the cytological appearances obtained by fine needle aspiration in a total of 47 primary nonsmall cell carcinomas. The presence of glands, cell balls, branching or papillary structures, cylindrical cells and nuclear grooving were major diagnostic indicators for adenocarcinoma. Cytoplasmic macrovacuoles were more common in adenocarcinomas (69\%) than in squamous (37\%) and large cell (50\%) carcinomas. Two or more of these features were combined in all well and moderately differentiated adenocarcinomas and in $67 \%$ of poorly differentiated adenocarcinoma. The major cytological indicators for squamous carcinomas were the presence of keratin and eosinophilic spindle cells with glassy or laminated cytoplasm. Granular cytoplasm was not specific for any histological type. A combination of the major features for both adeno- and squamous carcinoma was present in $58 \%$ of adenosquamous carcinomas, including some poorly differentiated types.

Correct typing could be obtained in almost all the well and moderately differentiated carcinomas and in about two thirds of the poorly differentiated tumours using FNA, provided that combinations and not individual variables are considered.
\end{abstract}

Fine needle aspiration (FNA) cytology is usually a reliable and accurate method for the diagnosis of pulmonary malignancy, with a high specificity and sensitivity and low false positive and negative rates. ${ }^{1-6}$ The accuracy of cytological typing of non-small cell carcinomas (NSCC), however, is poor, ${ }^{7}$ although FNA has been claimed to be more accurate. ${ }^{8}$ The aim of this study was to evaluate the cytological features of NSCC obtained by FNA using the histological type of the tumour, ${ }^{9}$ obtained by resection or at necropsy, to obtain more accurate typing using needle aspirates.

\section{Methods}

The cytohistological appearances of 58 lung tumours, obtained with fine needle aspirations over nine years were evaluated. Tumour tissue for histological examination was ob- tained by wedge resection, lobectomy, pneumonectomy, or at necropsy. The specimens were fixed in buffered formalin, embedded in paraffin wax, and routinely stained with haematoxylin and eosin, as well as with periodic acid Schiff diastase, alcian blue ( $\mathrm{pH}$ 2.5), and the World Health Organisation (WHO) stains. ${ }^{9}$ The sections were carefully screened by two pathologists (HRH and ARG) and tumour diagnosis agreed, using the second WHO histological classification of lung tumours. ${ }^{9}$ These comprised eight squamous cell carcinomas, 23 adenocarcinomas. Four large cell carcinomas, 12 adenosquamous carcinomas, three small cell carcinomas, two carcinoid tumours, one malignant fibrous histiocytoma, three secondary tumours (oesophagus, kidney, and thyroid), and two pulmonary hamartomas. Only the 47 primary non-small cell carcinomas were evaluated for this study (table 1 ). These were classified into well, moderately, and poorly differentiated. The adenocarcinomas were further subdivided into acinar or papillary according to the main architectural component; two tumours with equally predominant components were classified as papillary. Adenosquamous carcinomas were also subdivided according to their major component into predominantly squamous carcinoma or adenocarcinoma.

FNA was performed as described by Nordenstrom. ${ }^{1011}$ One to three smears fixed in alcohol that yielded abundant material for cytological interpretation were available for each case; all were stained with haematoxylin and eosin. The smears from the primary nonsmall cell carcinomas were carefully scruti-

Table 1 Histological classification of 47 primary nonsmall cell lung carcinomas according to WHO system?

Squamous cell carcinoma (8 cases)

Well (3) and moderately (1) differentiated Poorly differentiated

Adenocarcinoma (23 cases)

(a) Acinar adenocarcinoma

Well (5) and moderately (3) differentiated 8 Poorly differentiated

(b) Papillary adenocarcinom

Well (7) and moderately (1) differentiated

(c) Bronchiolo-alveolar carcinoma

(d) Solid carcinoma with mucus formation

Large cell carcinoma (4 cases)

(a) NOS

(b) Giant cell carcinoma

(c) Glear cell carcinoma

Adenosquamous carcinoma ( 12 cases)

(a) Predominantly squamous cell carcinoma Well (2) and moderately (5) differentiated

H R Harach

Correspondence to: Dr Allen Gibbs

Accepted for publication 12 June 1991 Poorly differentiated
(b) Predominantly adenocarcinoma Moderately differentiated Poorly differentiated


Table 2 "Adenocarcinoma" features in 47 carcinomas according to their histological type and degree of differentiation

\begin{tabular}{|c|c|c|c|c|c|c|}
\hline \multirow[b]{2}{*}{ Histological type (no) } & \multirow[b]{2}{*}{ Glands } & \multirow[b]{2}{*}{ Cell balls } & \multirow[b]{2}{*}{ Branching } & \multirow{2}{*}{$\begin{array}{l}\text { Cylindrical } \\
\text { cells }\end{array}$} & \multicolumn{2}{|c|}{ Cytoplasmic vacuoles } \\
\hline & & & & & Micro- & Macro- \\
\hline $\begin{array}{l}\text { Squamous cell carcinoma } \\
\text { Well/moderately (4) } \\
\text { Poor (4) }\end{array}$ & $\begin{array}{l}\mathbf{0} \\
\mathbf{0}\end{array}$ & $\begin{array}{l}\mathbf{0} \\
\mathbf{0}\end{array}$ & $\begin{array}{l}1 \\
0\end{array}$ & $\begin{array}{l}1 \\
1\end{array}$ & $\begin{array}{l}2 \\
1\end{array}$ & $\begin{array}{l}1 \\
2\end{array}$ \\
\hline $\begin{array}{l}\text { Large cell carcinoma } \\
\text { Undifferentiated (4) }\end{array}$ & 0 & 0 & 0 & 1 & 1 & 2 \\
\hline $\begin{array}{l}\text { Adenosquamous carcinoma } \\
\text { Well/moderately (9) } \\
\text { Poor (3) }\end{array}$ & $\begin{array}{l}4 \\
2\end{array}$ & $\begin{array}{l}3 \\
0\end{array}$ & $\begin{array}{l}3 \\
1\end{array}$ & $\begin{array}{l}4 \\
0\end{array}$ & $\begin{array}{l}7 \\
2\end{array}$ & $\begin{array}{l}2 \\
1\end{array}$ \\
\hline $\begin{array}{l}\text { Adenocarcinomas } \\
\text { Well/moderately differentiated } \\
\text { Acinar (8) } \\
\text { Papillary (8) } \\
\text { Bronchiol-alveolar (3) }\end{array}$ & $\begin{array}{l}5 \\
5 \\
1\end{array}$ & $\begin{array}{l}3 \\
\mathbf{4} \\
\mathbf{3}\end{array}$ & $\begin{array}{l}5 \\
5 \\
2\end{array}$ & $\begin{array}{l}7 \\
8 \\
3\end{array}$ & $\begin{array}{l}8 \\
8 \\
2\end{array}$ & $\begin{array}{l}7 \\
6 \\
2\end{array}$ \\
\hline $\begin{array}{l}\text { Poorly differentiated } \\
\text { Acinar (3) } \\
\text { Solid (1) }\end{array}$ & $\begin{array}{l}\mathbf{0} \\
\mathbf{0}\end{array}$ & $\begin{array}{l}1 \\
0\end{array}$ & $\begin{array}{l}\mathbf{0} \\
\mathbf{0}\end{array}$ & $\begin{array}{l}1 \\
0\end{array}$ & $\begin{array}{l}3 \\
1\end{array}$ & $\begin{array}{l}0 \\
1\end{array}$ \\
\hline
\end{tabular}

All the features were greater than grade 2.

nised by one of us (SBZH) without knowledge of the histological diagnosis of the tumours. The various features that may be observed in lung carcinomas were analysed according to current cytological criteria ${ }^{1213}$ and the following features were assessed:

(a) Cell type: oval, round, cylindrical, spindle, small, large, pleomorphic, multinucleated, and ghost cells;

(b) Cytoplasmic features: scanty, abundant, microvacuolated or macrovacuolated, clear, eosinophilic granular, glassy or keratinised and laminated (due to cytoplasmic tonofilaments), well demarcated;

(c) Nuclear characteristics: size and shape as for cell type, hyperchromatic with coarse or finely granular chromatin, pale or vesicular, and pyknotic. The nucleoli, when present, were recorded as single or multiple, and small

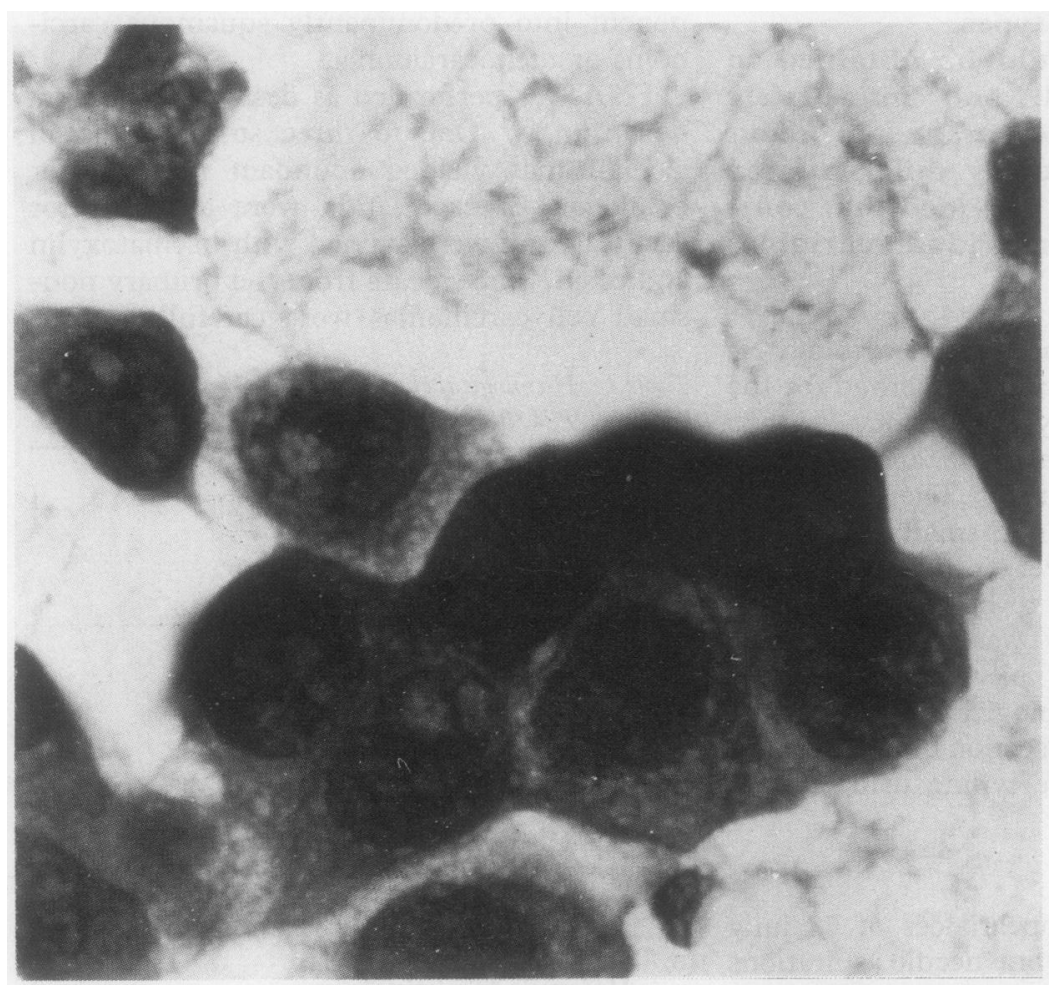

Figure 1 . Adenocarcinoma: clusters of well demarcated cells showing nuclear grooving. or prominent. Special attention was paid to the presence of nuclear cytoplasmic inclusions and grooving which were only regarded as a feature in neoplastic cells showing little or no pleomorphism. These changes were semiquantitatively graded from 1 (occasional) to 4 (frequent). Cellular arrangement was recorded as: single; clusters; sheets; glands; balls; branching or papillary structures; overlapping; monolayered; tight or loose. The presence of background keratin and mucus was also recorded.

\section{Results}

ADENOGARCINOMA

Morphological features did not clearly differentiate between well and moderately differentiated carcinomas. There was no difference between acinar, papillary and bronchiolo-alveolar carcinomas. Therefore the features are described together.

Well and moderately differentiated

In all cases the tumour cells tended to form tight sheets and overlapped. Single cells $(16 \%)$ and loose clusters (5\%) were observed in a few cases. Monolayered clusters occurred in $89 \%$ of cases, the cells being well demarcated in $40 \%$. The neoplastic cells were usually round to oval in shape. Cylindrical cells occurred in $89 \%$ of cases. The cell cytoplasm was usually abundant and contained micro- and macrovacuoles (table 2). The nuclear chromatin was often finely or coarsely granular; pale (10\%) and hyperchromatic (5\%) nuclei occasionally occurred. Nucleoli were usually single and prominent but occasionally multiple (5\%). Nuclear grooving and cytoplasmic inclusions were observed in $100 \%$ and $63 \%$ of the cases, respectively (figs 1 and 2) (table 3). Glands, cell balls, and papillary or branching structures were found in $58 \%, 53 \%$, and $63 \%$ of the cases, respectively (fig 3) (table 2). One or more of these patterns were present in $87 \%$ of the smears. Large cells and pleomorphic cells with bizarre nuclei were observed in $53 \%$ and $69 \%$ of the cases, respectively. Multinucleated cells 


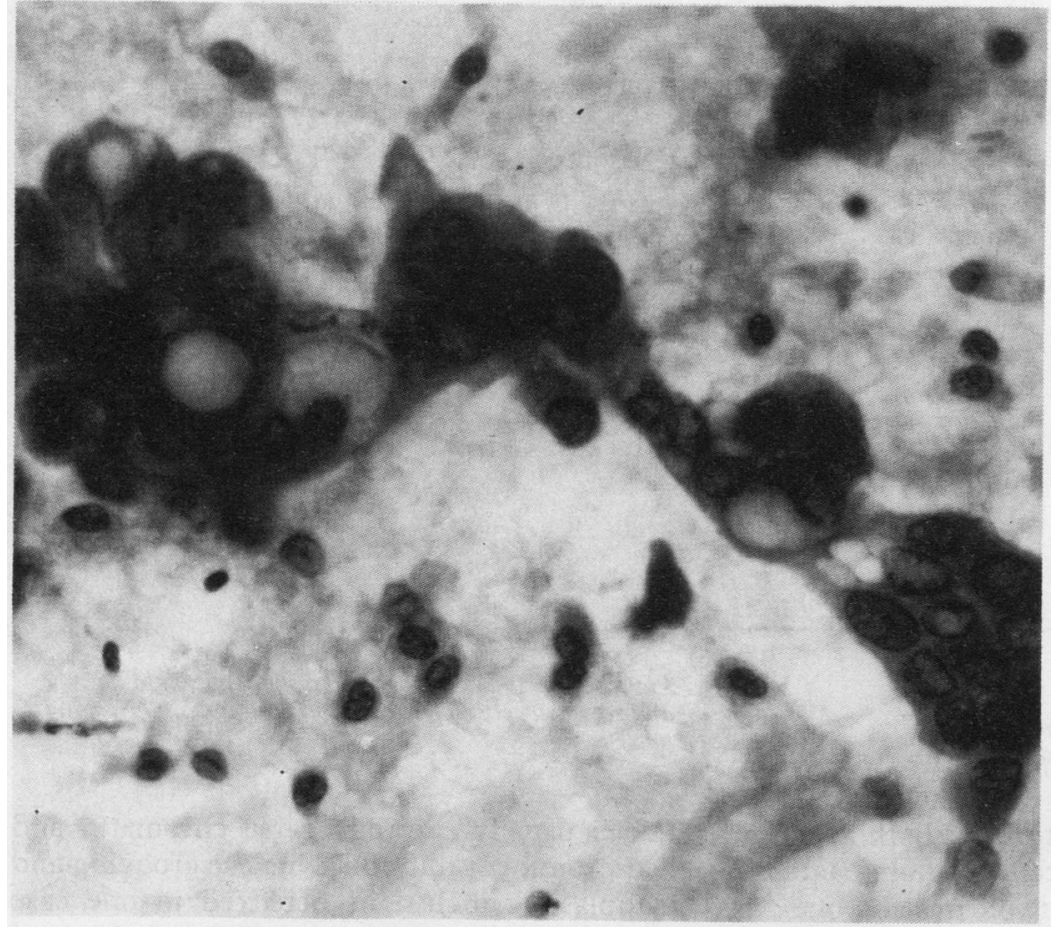

Figure 2 Adenocarcinoma: clusters of cells, some showing macrovacuoles.

$(10 \%)$ were rare. There was an almost twofold decrease of these cell types when grade 3 or greater was considered. Background mucus occurred in a quarter of the smears. The only solid carcinoma with mucus formation showed large cells which were round to oval in shape, often with micro- and macrovacuolated cytoplasm lying singly or arranged loosely in sheets. Pleomorphic cells were also present. The nuclei usually showed coarse chromatin and had small nucleoli. Nuclear grooving occurred in neoplastic cells but not in nuclear cytoplasmic inclusions.

\section{Poorly differentiated}

Neoplastic cells occurred in tight sheets and overlapped. Monolayered clusters were present in one case. Most cells were round to oval in shape. The nuclei usually showed coarse chromatin and had prominent nucleoli (fig 4). Features of adenocarcinoma were identified in two cases. One of these showed cylindrical cells and nuclear grooving, and the other cell balls. Both cases had cells with cytoplastic microvacuoles. The third case

Table 3 Lung carcinomas with nuclear grooving and cytoplasmic inclusions according to histological type and degree of differentiation

\begin{tabular}{|c|c|c|c|c|}
\hline \multirow[b]{2}{*}{ Histological types (no of cases) } & \multicolumn{2}{|l|}{ Grooving } & \multicolumn{2}{|c|}{ Cytoplasmic inclusion } \\
\hline & Grade 2 & Grade 3 & Grade 2 & Grade 3 \\
\hline $\begin{array}{l}\text { Well/moderately differentiated: } \\
\text { Adenocarcinomas (19) } \\
\text { Squamous cell (4) } \\
\text { Adenosquamous (9) }\end{array}$ & $\begin{array}{l}3(16 \%) \\
3(33 \%)\end{array}$ & $\begin{array}{c}16 \star(84 \%) \\
1(25 \%) \\
3(33 \%)\end{array}$ & $\begin{array}{l}3(16 \%) \\
3(33 \%)\end{array}$ & $9(47 \%)$ \\
\hline $\begin{array}{l}\text { Poorly differentiated: } \\
\text { Adenocarcinoma (3) } \\
\text { Squamous cell (4) } \\
\text { Adenosquamous (3) }\end{array}$ & $1(25 \%)$ & $\begin{array}{l}2(67 \%) \\
1(25 \%) \\
1(33 \%)\end{array}$ & $1(25 \%)$ & $1(33 \%)$ \\
\hline Large cell undifferentiated (4) & & $3(75 \%)$ & $1(25 \%)$ & $2(50 \%)$ \\
\hline
\end{tabular}

The solid adenocarcinoma with mucus formation is not included.

ॠThis group showed the only one case with $4+$ from the whole series. showed only cells with nuclear grooving as a distinctive feature (tables 2 and 3). Pleomorphic cells and large cells were present in one and two cases, respectively.

\section{SQUAMOUS CELL CARCINOMA}

\section{Well and moderately differentiated}

Tumour cells were generally arranged in tight sheets and overlapped. Single cells and monolayered clusters, sometimes with cells loosely packed or well demarcated, were also present. The neoplastic cells were oval to elongated in shape with abundant, eosinophilic, granular and sometimes laminated cytoplasm (table 4). Spindle cells with similar cytoplasmic features were present in half of the cases. The nuclei, usually hyperchromatic, showed finely granular chromatin and often small nucleoli. Ghost cells as well as cells showing cytoplasm with a glassy appearance and pyknotic nuclei also occurred. These elements are usually related to keratinisation which was present in variable amounts in all four cases (figs 5 and 6). Large and pleomorphic cells with bizarre nuclei were always present and, in one case, multinucleated cells occurred. Nuclear grooving was present in one case (table 3). Branching structures were seen in one case; microvacuolated and macrovacuolated cells were seen in about one third of the cases (table 2).

\section{Poorly differentiated}

Neoplastic cells were arranged in tight sheets, often overlapping. They were elongated in shape and had eosinophilic and, in three cases, granular cytoplasm. Cells with glassy cytoplasm occurred in two cases, spindle-shaped cells were present in one. The nuclei showed coarse chromatin and prominent nucleoli. Keratin was present in minimal amounts in three of the four cases. One case had eosinophilic granular cells and nuclear grooving as distinctive features. Nuclear grooving was evident in another case that also showed nuclear cytoplasmic inclusions.

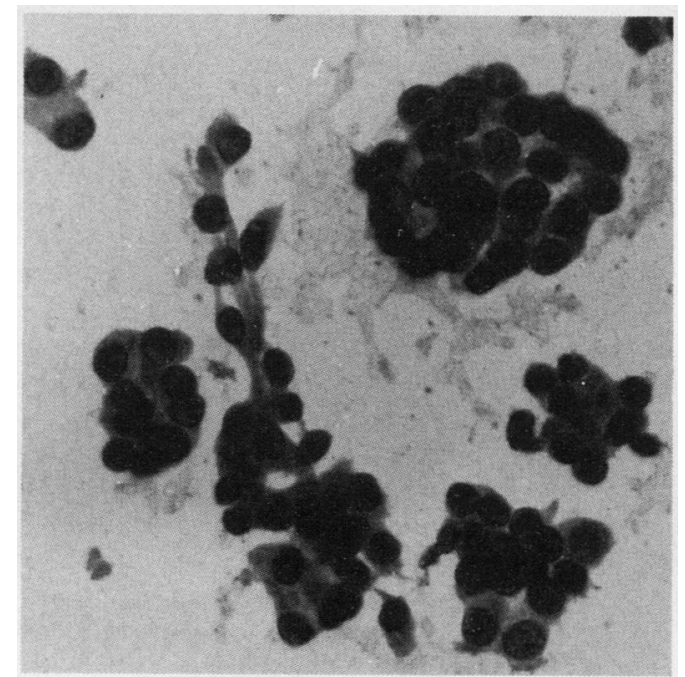

Figure 3 Adenocarcinoma: cell balls and branching structures. 
Table 4 "Squamous" features in 47 carcinomas according to histological type and degree of differentiation

\begin{tabular}{|c|c|c|c|c|c|}
\hline Tumour type & $\begin{array}{l}\text { Differentiation } \\
\text { (no) }\end{array}$ & $\begin{array}{l}\text { Spindle } \\
\text { cells }\end{array}$ & $\begin{array}{l}\text { Glassy } \\
\text { cells }\end{array}$ & $\begin{array}{l}\text { Gramulocyte } \\
\text { cells }\end{array}$ & Keratin \\
\hline $\begin{array}{l}\text { Squamous } \\
\text { Well/moderate } \\
\text { Poorly differentiated }\end{array}$ & $\begin{array}{l}(4) \\
(4)\end{array}$ & $\begin{array}{l}2 \\
1\end{array}$ & $\begin{array}{l}2 \\
2\end{array}$ & $\begin{array}{l}2 \\
1\end{array}$ & $\begin{array}{l}3 \\
3\end{array}$ \\
\hline $\begin{array}{l}\text { Large cell } \\
\text { Undifferentiated }\end{array}$ & (4) & 0 & 1 & 3 & 0 \\
\hline $\begin{array}{l}\text { Adenocarcinoma } \\
\text { Well/moderate } \\
\text { Acinar } \\
\text { Papillary } \\
\text { Bronchiolo-alveolar }\end{array}$ & $\begin{array}{l}(8) \\
(8) \\
(3)\end{array}$ & $\begin{array}{l}0 \\
0 \\
0\end{array}$ & $\begin{array}{l}0 \\
0 \\
0\end{array}$ & $\begin{array}{l}1 \\
1 \\
1\end{array}$ & $\begin{array}{l}0 \\
0 \\
0\end{array}$ \\
\hline $\begin{array}{l}\text { Poorly differentiated } \\
\text { Acinar } \\
\text { Solid }\end{array}$ & $\begin{array}{l}(3) \\
(1)\end{array}$ & $\begin{array}{l}0 \\
0\end{array}$ & $\begin{array}{l}0 \\
0\end{array}$ & $\begin{array}{l}1 \\
1\end{array}$ & $\begin{array}{l}0 \\
0\end{array}$ \\
\hline $\begin{array}{l}\text { Adenosquamous } \\
\text { Well/moderate } \\
\text { Poor }\end{array}$ & $\begin{array}{l}\text { (9) } \\
\text { (3) }\end{array}$ & $\begin{array}{l}3 \\
0\end{array}$ & $\begin{array}{l}1 \\
1\end{array}$ & $\begin{array}{l}3 \\
2\end{array}$ & $\begin{array}{l}6 \\
0\end{array}$ \\
\hline
\end{tabular}

\section{ADENOSQUAMOUS CARCINOMA}

\section{Well and moderately differentiated}

Sixty seven per cent of the tumours (six cases) showed cytological features of both adenocarcinoma and squamous cell carcinoma (tables 24); the other tumours (two cases and one case, respectively) had features of either a glandular or squamous component, respectively. The pattern of cytological presentation did not always correlate with the predominant histological type. Nuclear grooving and cytoplasmic inclusions were present in $67 \%$ and $33 \%$ of the cases, respectively (table 3 ).

\section{Poorly differentiated}

Neoplastic cells occurred in tight sheets and overlapped. Monolayered clusters were present in two cases and a branching pattern in one. Most cells were round to oval in shape often with abundant vacuolated cytoplasm containing microvacuoles or macrovacuoles. The

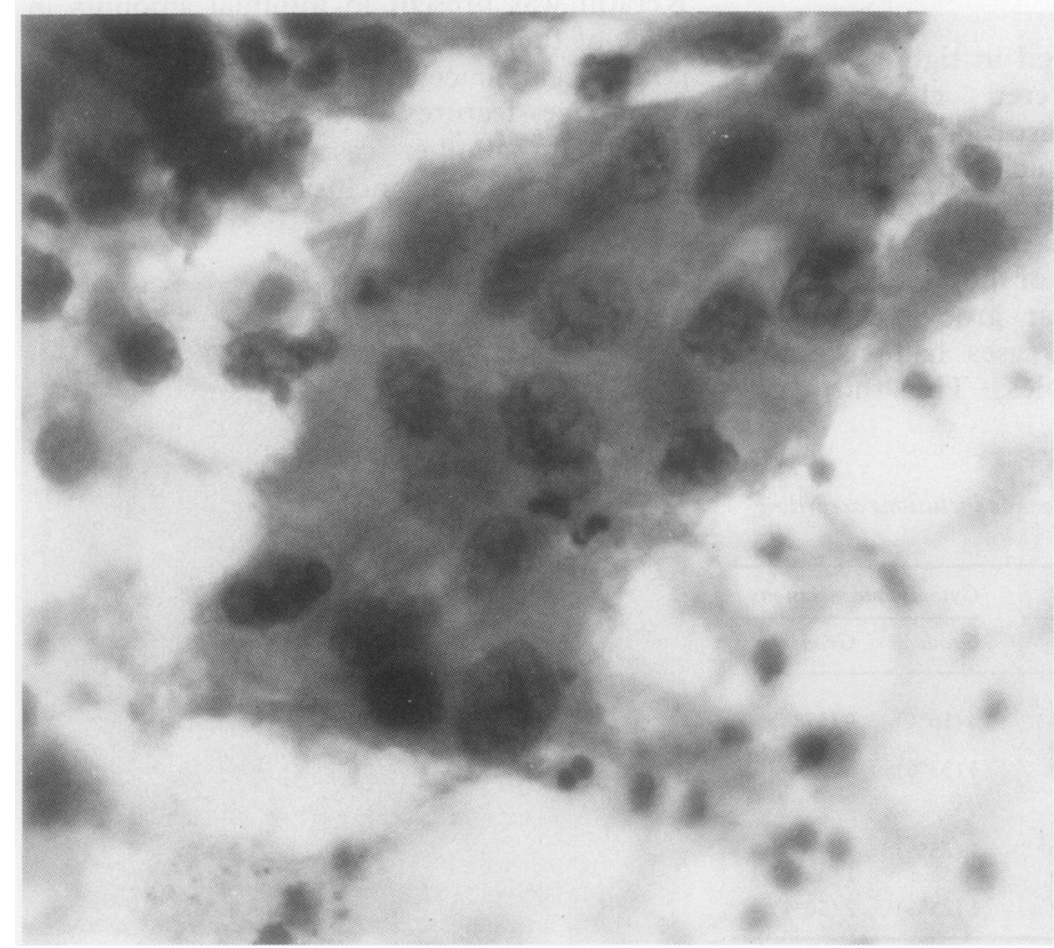

Figure 4 Poorly differentiated adenocarcinoma showing macrovacuoles.

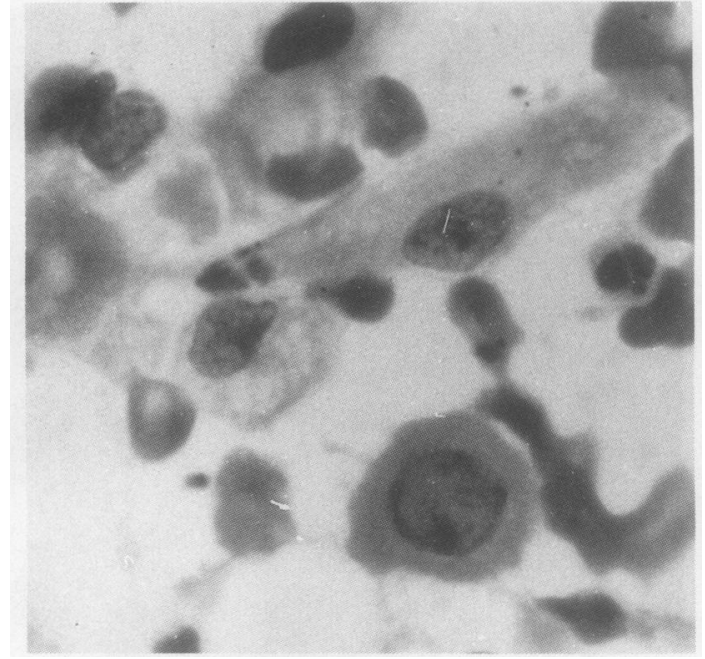

Figure 5 Squamous carcinoma showing single spindle and rounded cells. There is a cell with a dense pyknotic nucleus.

nuclei usually showed coarse chromatin and had prominent nucleoli. Nuclear grooving and cytoplasmic inclusions occurred in one case each, respectively (table 3). Pleomorphic and large cells were present in two cases. One tumour had the distinct cytological features of adenosquamous carcinoma: the other two cases showed characteristics of one component each.

LARGE CELL UNDIFFERENTIATED CARCINOMA

The neoplastic cells occurred singly or were arranged in tight or, more frequently, loose sheets. Most of the cells were large and had abundant cytoplasm with large hyperchromatic, oval, or bizarre pleomorphic nuclei with prominent, sometimes multiple, nucleoli. Cytoplasmic vacuoles were present in three of the four cases. Multinucleated giant cells occurred in three cases.

Nuclear grooving and cytoplasmic inclusions, only present in large and pleomorphic cells with irregular nuclei, occurred in three cases (table 3).

\section{Discussion}

In previous studies there was a wide range of cytohistological agreement in non-small cell carcinomas of the lung, from $72 \%$ to $100 \%$ for squamous cell carcinoma, $29 \%$ to $100 \%$ for adenocarcinoma, and $19 \%$ to $74 \%$ for large cell undifferentiated carcinoma. ${ }^{451214-18}$ Even in biopsy specimens a wide intra- and interobserver variability has been shown. ${ }^{19}{ }^{20}$ Immunohistochemistry does not seem to be of great value in the subclassification of non-small cell carcinomas. ${ }^{21}$ In general, pulmonary cytology has been more accurate in the diagnosis of well to moderately differentiated carcinomas, than in poorly differentiated and undifferentiated carcinomas. ${ }^{22}{ }^{23}$ One reason has been the lack of rigid cytological and histological criteria used for the various tumour types. ${ }^{24}$ Therefore, we decided to evaluate certain cytological features and correlate them with a series of lung carcinomas classified according to the WHO system. ${ }^{9}$ Our findings indicate that no cytological distinction between the subtypes of adenocar- 
Figure 6 Squamous carcinoma showing laminated keratinised cells.

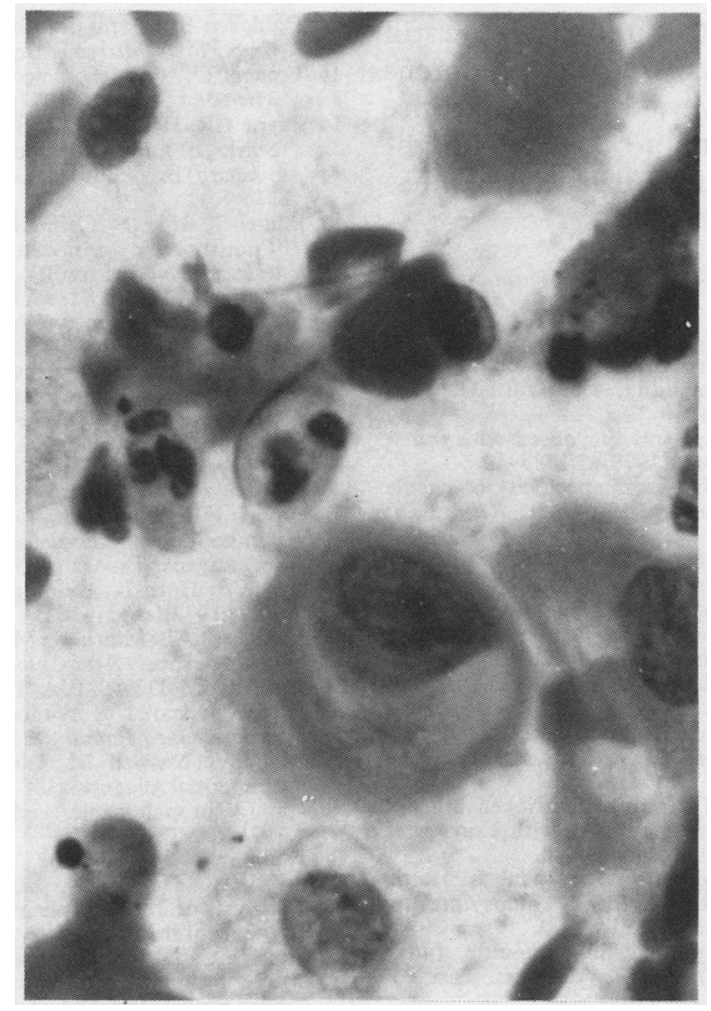

cinomas of the lung could be distinguished from FNA. Previous studies suggested that adenocarcinomas could be differentiated from bronchioloalveolar carcinomas on exfoliative material. ${ }^{25}$ This discrepancy may be related to the smaller number of bronchioloalveolar tumours contained in this study, or, more likely, to the morphological variables used for their typing. Another factor to consider is the diagnosis of bronchio-alveolar carcinoma which relies on architecture, and it is not surprising, therefore, that it can only reliably be diagnosed in histological sections. The presence of glands, cell balls, branching or papillary structures, cylindrical neoplastic' cells, and cytoplasmic macrovacuoles were considered here as major diagnostic indicators for adenocarcinomas regardless of their histological type. ${ }^{51213}$ Cytoplasmic macrovacuoles, however, were observed in three out of the eight squamous carcinomas; this makes it unreliable on its own as a specific feature of adenocarcinoma. When two or more of these variables were present in combination diagnostic accuracy was $100 \%$ for well and moderately differentiated adenocarcinomas, as well as for two of the three poorly differentiated tumours where either cylindrical cells or cell balls, together with cytoplasmic vacuoles, were present. Nuclear grooving and cytoplasmic inclusions in round to oval and cylindrical cells were present in $96 \%$ and $52 \%$, respectively, of the total series of adenocarcinomas studied. These characteristics, combined, seem to be useful as a complementary criterion for detecting or suspecting these lung tumours. They also occurred frequently in large cell undifferentiated carcinomas, but in cells with large pleomorphic nuclei. Nuclear cytoplasmic inclusions have been noted in bronchiolo- alveolar and papillary adenocarcinomas of the lung, ${ }^{526}$ but not nuclear grooving to our knowledge. These two features were found to be important cytological criteria for diagnosing thyroid papillary carcinoma, ${ }^{27}$ even in its smallest variants, ${ }^{28}$ though we found no special predilection for neoplastic cells of papillary carcinoma or any other type of lung adenocarcinomas in this survey. Nuclear grooves also occurred in two poorly differentiated adenocarcinomas. The other case, the only solid adenocarcinoma with mucus formation studied, showed nuclear grooving without any of the other major cytological criteria for diagnosing adenocarcinoma.

In agreement with previous observations, ${ }^{512}$ we found that the major distinctive cytological features for bronchial squamous cell carcinomas were the presence of keratin and eosinophilic, spindle, or elongated cells with glassy, granular, or laminated cytoplasm. Seven of the eight tumours studied, including three poorly differentiated, contained minimal to large amounts of keratin in the smears in combination with at least one of the above mentioned cell types. One poorly differentiated squamous carcinoma only showed elongated cells with eosinophilic granular cytoplasm and nuclear grooving. In this case the possibility of adenosquamous carcinoma cannot be excluded. Granular cytoplasm, however, was seen in a small proportion of the other histological types. Previous multidisciplinary studies have suggested that cytology can be more accurate for typing lung tumours than conventional histology.24 29

Our findings show that a combination of the major features that may be observed in squamous cell carcinomas, and adenocarcinomas can be cytologically diagnostic for adenosquamous carcinoma in $58 \%$ of the cases, including some poorly differentiated types. The other cases could have been diagnosed solely as either adenocarcinoma or squamous cell carcinoma, regardless of their degree of differentiation. This should be expected as sampling of cytological material might include one or both tumour components. Similar results have been shown by other authors. ${ }^{22} 29$ Early studies have emphasised the difficulties of differentiating cytologically large cell undifferentiated carcinomas from other carcinomas of the lung, mainly poorly differentiated tumours. ${ }^{42-2429}$ Our results suggest that diagnosis of large cell undifferentiated carcinomas should be suspected both by the presence of tight and loose clusters of large cells accompanied by pleomorphic, bizarre, and multinucleated neoplastic cells, and by the absence of glands, cell balls, branching structures, spindle and keratinised cells. These observations should be tested on a larger series of large cell undifferentiated carcinomas.

According to our observations correct typing of poorly differentiated carcinomas could be achieved in about two thirds of the cases, regardless of their histological type, when following the main diagnostic variables used for the more differentiated counterparts. These observations need to be tested in a prospective 
survey to establish their true utility. We are still left with a small proportion of poorly differentiated tumours, however, where a precise cytological diagnosis cannot be made on light microscopy. Perhaps ultrastructural studies might have an important role. ${ }^{29} 30$

1 Francis D, Hojgaard K. Transthoracic aspiration biopsy: A tudy on diagnostic reproducibility. Acta Pathol Microbio Scand $(A)$ 1977;85:889-96.

2 Sinner WN. Pulmonary neoplasms diagnosed with transthoracic needle biopsy. Cancer 1979;43:1533-40.

3 Poe RH, Tobin RE. Sensitivity and specificity of needle biopsy in lung malignancy. $A m$ Rev Respir Dis 1980;122:725-9.

4 Taft PD, Szyfelbein WM, Greene R. A study of variability in cytologic diagnoses based on pulmonary aspiration specimens. Am J Clin Pathol 1980;73:36-40.

5 Sterrett G, Whitaker D, Glancy J. Fine-needle aspiration of lung, mediastinum, and chest wall. A clinicopathologic lung, medisstinum, and chest wall. A clinicopath

6 Yazdi HM, MacDonald LL, Hickey NM. Thoracic fine needle aspiration biopsy versus fine needle cutting biopsy: A comparative study of 40 patients. Acta Cytol 1988;32:635-40.

7 Suprun H, Pedio G, Ruttner JR. The diagnostic reliability of cytologic typing in primary lung cancer with a review of the literature. Acta Cytol 1980;24:494-500.

8 Dahlgren SE, Lind B. Comparison between diagnostic results obtained by transthoracic needle biopsy and by sputum cytology. Acta Cytol 1972;16:53-8.

9 Kreyberg L. Histological typing of lung tumours. International histological classification of tumours. 2nd ed. national histological clas

10 Dahlgren SE, Nordenstrom B. Transthoracic needle biopsy. Stoctholm: Almqvist \& Wiksell, 1966.

11 Nordenstrom BEW. Technical aspects of obtaining cellular material from lesions deep in the lung: $A$ radiologist's view and description of the screw-needle sampling technique. Acta Cytol 1984;28:233-42.

12 Johnston WW. Cytologic diagnosis of lung cancer: Principles and problems. Pathol Res Pract 1986;181:1-36.

13 Koss LG, Woyke S, Olszewski W. The lung, pleura and mediastinum. In: Aspiration biopsy. Cytologic interpretation and histologic bases. Tokyo: Igaku-Shoin, 1984: 287-349.
14 Dahlgren SE. Aspiration biopsy of intrathoracic tumours. Acta Pathol Microbiol Scand 1967;70:566-76.

15 Francis D. Transthoracic aspiration biopsy. Acta Pathol Microbiol Scand(A) 1977;85:535-8.

16 Payne CR, Hadfield JW, Stovin PG, Barker V, Heard BE, Stark JE. Direnostic accuracy of cytology and biopsy in primary bronchial carcinoma. J Clin Pathol 1981;34: primar 8 .

17 Pilotti S, Rilke F, Gribauldi G, Damascelli B, Ravasi G. Transthoracic fine needle aspiration biopsy in pulmonary lesions: Updated results. Acta Cytol 1984;28:225-32.

18 Zaman MB, Hadju SI, Melamed MR, Watson RC. Transthoracic aspiration cytology of pulmonary lesions. Semin Diagnost Pathol 1986;3:176-87.

19 Yesner R, Gerstl B, Auerbach O. Application of the World Health Organization classification of lung carcinoma to biopsy material. Ann Thorac Surg 1965;1:33-49.

20 Feinstein AR, Gelfman NA, Yesner R. Observer variability in the histopathologic diagnosis of lung cancer. Am Rev Respir Dis 1970;101:671-84.

21 Harach HR, Skinner M, Gibbs AR. Biological markers in human lung carcinoma: an immunopathological study of human lung carcinoma: an immunopatigens. Thorax 1983;38:937-41.

22 Lange E, Hoeg K. Cytologic typing of lung cancer. Acta Cytol 1972;16:327-30.

23 Kanhouwa SB, Matthews MJ. Reliability of cytologic typing of lung cancer. Acta Cytol 1976;20:229-32.

24 Hess FG, McDowell EM, Trump BF. Pulmonary cytology: Current status of cytologic typing of respiratory tract tumors. Am J Pathol 1981(a);103:323-33.

25 Roger V, Nassiell M, Linden M, Enstad I. Cytologic differential diagnosis of bronchiolo-alveolar carcinom and bronchogenic adenocarcinoma. Acta Cytol 1976;20:303-7.

26 Tsumuraya $M$, Kodama $T$, Kameya $T$, Shimosato $Y$, Koketsu H, Uei $Y$. Light and electron microscopic analysis of intranuclear inclusions in papillary adenocaranalysis of intranuclear inclusions in papillary

27 Chan JKC, Saw D. The grooved nucleus: A useful diagnostic criterion of papillary carcinoma of the thyroid. Am tic criterion of papillary carcin
Surg Pathol 1986;10:672-9.

28 Harach HR, Franssila KO, Wasenius VM. Occult papillar carcinoma of the thyroid: A "normal" finding in Finland. A systematic autopsy study. Cancer 1985;56:531-8.

29 Mennemeyer R, Hammar SP, Bauermeister DE, Wheelis RF, Jones HW, Bartha M. Cytologic, histologic and electron microscopic correlations in poorly differentiated primary lung carcinoma. A study of 43 cases. Acta Cytol 1979;23:297-302.

30 Hess FG, McDowell EM, Trump BF. The respiratory epithelium VIII. Interpretation of cytologic criteria for human and hamster respiratory tract tumors. Acta Cytol 1981;25:111-34. 